\title{
Determinants of Online Purchase Intention in Indonesia
}

\author{
Sugeng Hariadi ${ }^{1, *} \&$ Siti Rahayu ${ }^{2}$
}

\author{
${ }^{I}$ University of Surabaya, Surabaya, Indonesia \\ ${ }^{2}$ University of Surabaya, Surabaya, Indonesia \\ *Corresponding author. Email: sugeng.hariadi@staff.ubaya.ac.id
}

\begin{abstract}
This research discusses the influence of online customer experience and perceived risk on online purchase intention in Indonesia. This study has nine variables: online customer experience, product risk, financial risk, privacy risk, security risk, time risk, social risk, psychological risk, and online purchase intention, with 15 hypotheses. The sampling technique used is non-probability sampling with purposive sampling technique. Data were collected mainly by distributing questionnaires and obtained 185 respondents. Respondents must be over 17 years old and have made online purchases at e-commerce services in Indonesia. The SEM method using SPSS Statistics 24 and AMOS 22 was performed for analysis. The results show four hypotheses are supported and eleven hypotheses are not.
\end{abstract}

Keywords: online customer experience, social risk, psychological risk, online purchase intention.

\section{INTRODUCTION}

During the Covid-19 pandemic, online shopping has become an essential instrument around the world. Online shopping has attracted many consumers and has become a popular shopping style (Bourlakis et al. 2008). The number of online business-toconsumer (B2C) sales transactions has increased in almost all world regions. In fact, total e-commerce retail sales worldwide are expected to continue to soar and will reach US\$ 4.479 trillion in 2021 (iMarketology 2020). According to Global Web Index, Indonesia was the country with the highest ecommerce adoption rate globally in 2019. In Indonesia, $90 \%$ of internet users aged 16-64 have purchased products and services online.

The e-commerce industry is changing the lifestyle of consumers as well as opening up new business opportunities. It also produces trickle-effects for industries in the supporting sectors, namely logistics, IT infrastruc- ture, and e-commerce operators (CNN Indonesia 2020).

The online shopping trend has become an interesting topic for researchers. Several studies have emphasized the vital role of the customer experience in online shopping. Johnston \& Kong (2011) identify the importance of online customer experience for companies because it affects customer satisfaction. Grewal et al. (2009) state that retailers must focus on the online customer experience to compete effectively in today's competitive and dynamic environment.

Although the online shopping and ecommerce infrastructure are experiencing growth, many new problems and challenges have emerged. Online shopping is still considered a risky activity. Some of the new problems and challenges most internet users face are payment security, data protection, contract validity and validity, insufficient disclosure of information, product quality, and enforcement of rights (Paynter \& Lim 2001). 
Various risks in online purchases often affect purchase intention. This is also often an excuse for customers not to buy online. Several studies also reveal that perceptions of risk play an important role when shopping online. Perceptions of risk make consumers feel insecure in making purchase decisions (Dowling \& Staelin 1994, Dabrynin \& Zhang 2019).

The concept of risk that consumers perceive in marketing was first introduced by Bauer \& Bauer (1960). This topic has grown into a broad discussion. In online shopping activities, the level of perceived risk is greater because of limited access to products and salespeople (Forsythe \& Shi 2003).

Apart from the risky online shopping infrastructure, online shopping is also a risky activity in the e-marketplace. Customers often suffer losses due to unsatisfactory products and are not worth the price. The products purchased are often not shown on the website, for example, color, shape, and appearance. Other risks are related to security and delivery.

In addition, online shoppers may feel a loss of self-esteem due to frustration of not achieving purchase goals, dissatisfaction when choosing products, or disappointment over poor service (Ariffin et al. 2019). Perception of risk is an essential topic because human perception is the main trigger behind how a person behaves. Their perceptions trigger their choices, intentions, and behavior. To learn consumer behavior, it is necessary to identify consumer perceptions. This way, it will be easier for vendors to satisfy and learn about the inside of the consumer (Arshad et al. 2015).

Customer experience is one of the essential issues in business (Verhoef et al. 2009). The online customer experience affects customer perceptions and their positive intention to buy online (Zhou et al. 2007, Kuhlmeier \& Knight 2005).

In this study, the authors will examine how the effects of online customer experience on perceived risk. Perceived risks in this study are product risk, privacy risk, financial risk, security risk, time risk, social risk, and psychological risk. In addition, this study will also look at how 7 perceived risk factors affect online purchase intention.

Johnston \& Kong (2011) identify the importance of online customer experience for companies because this will affect customer satisfaction. Bhatnagar et al. (2000) suggest that risks related to product unreliability are likely to have a negative impact on online purchase intentions. Pallab (1996) states that the internet has a low level of security that will make consumers worry about using their credit cards or disclosing personal information. Hsu \& Bayarsaikham (2012) suggest that security risks negatively impact online purchase intentions for clothing.

Time risk, based on the research results, occurs when there are no actual product photos on the website and consumers may have to select product images by searching for them on separate websites, and time spent on images that are loaded will be considered a time risk (Forsythe et al. 2006). Social risk refers to an assessment given to the purchased products, making people around such as family, friends, and society feel dissatisfied with the products (Dowling \& Staelin 1994). Psychological risk can be defined as consumer dissatisfaction in choosing a bad product or service (Ueltschy et al. 2004).

Online purchase intention will determine the strength of customer intention to carry out shopping behavior via the internet (Salisbury et al. 2001). Masoud (2013) stipulates that any form of financial loss can occur either through credit card fraud, lower quality, or products that do not perform as expected, and this hinders online shopping and has a strong negative effect on online purchase intention. Garbarino \& Strahilevitz (2004) acknowledge privacy risk as to the probability that personal information is stolen during online transactions, resulting in a negative impact on consumer interest in online shopping. Security risk is defined as potential loss due to online fraud or hacking that exposes the security of internet transactions or online users (Soltanpanah et al. 2012). Then time risk will also hinder consumer purchase interest to buy online when 
consumers need much time to find suitable products through a website (Forsythe et al. 2006). Social risk is also recognized as the level of customer confidence that consumers will be evaluated negatively and judged because of product (brand) preferences (Semeijn et al. 2004). Psychological risk can be defined as consumer dissatisfaction in choosing a bad product or service (Ueltschy et al. 2004).

This study focuses on cases in Indonesia. In Indonesia, e-commerce is experiencing rapid growth. In addition, the government is encouraging people to carry out selfquarantine and physical distancing due to the Covid-19 pandemic. The amount of online shopping has also increased. This study attempts to combine the research models of Dabrynin \& Zhang (2019) and Ariffin et al. (2019).

\section{RESEARCH METHODS}

To identify the level and nature of the causeeffect relationship, this study is included in the category of causal research or explanatory research (Zikmund et al. 2012). Causal studies focus on analyzing a particular situation or problem to explain the pattern of relationships between variables (Sekaran 2000). Data sources used in this study are primary data, namely data obtained directly from respondents through distributing questionnaires. Respondents in this study were people who have done online shopping in the past year. In this study, the data processing method used IBM SPSS Statistics 22.0 for windows and SEM (structural equation modeling) software with AMOS 22.

\section{RESULTS AND DISCUSSIONS}

\subsection{Respondent identity}

The total respondents of this study were 185 , with $22 \%$ were males, and $78 \%$ were females. Respondents aged 21-25 years were $51 \%$, aged $17-20$ years were $43 \%$, and 26 years or over were $6 \%$. Regarding education level, respondents with the last high school education were $76.2 \%$, and those with Diploma, S1, and S2 education were $23.8 \%$.

\subsection{Measurement model}

This study uses the Amos 22.0 software for measurement. All variables and indicators are measured by the CFA method. If this measurement model has a Goodness-of-fit index value, including the indexes, namely CMIN / DF, RMSEA, GFI, and CFI, then processing can be done. Data processing results show that each indicator of the online customer experience variable has a standardized loadings value greater than 0.5 with an AVE of 0.674 and a CR generated above 0.7 , which is 0.861 . This means that the indicators of the online customer experience variable have good reliability.

\begin{tabular}{cccc}
\multicolumn{4}{c}{ Table 1. Measurement Model's Goodness of Fit. } \\
\hline Goodness of fit & Criteria & $\begin{array}{l}\text { Model } \\
\text { Result }\end{array}$ & Description \\
\hline CMIN/DF & $\Omega 3.00$ & 1.336 & Good Fit \\
RMSEA & $\Omega 0.08$ & 0.043 & Good Fit \\
GFI & $m 0.90$ & 0.829 & Marginal Fit \\
TLI & m 0.90 & 0.923 & Good Fit \\
CFI & m 0.90 & 0.932 & Good Fit \\
\hline
\end{tabular}

Financial risk, product risk, privacy risk, security risk, time risk, social risk, and psychological risk variables have a standardized loadings value greater than 0.5 with an AVE of 0.514 and a CR generated above 0.7, which is 0.808 . This shows that the indicators of the seven perceived risk variables have good reliability.

The online purchase intention variable has a standardized loadings value greater than 0.5 with an AVE of 0.600 and a CR generated above 0.7 , which is 0.881 . This shows that the indicators of the online purchase intention variable have good reliability. Table 1 shows that the CMIN/DF value is $1.336<3$, meaning that the model tested meets the required criteria (Good Fit). The RMSEA value is $0.043<0.08$. These results indicate that the model tested meets the required criteria (Good fit). The GFI value is 0.829 , which means marginal fit. The GFI value is less than the required value but is 
still supported because it is still close to the required value (Wijayanto 2008). Values for the TLI range from 0 to 1 . Table 1 shows the TLI value $0.923>0.90$. These results indicate that the model tested meets the required criteria (Good fit). CFI value 0.932>0.90. These results indicate that the model tested meets the required criteria (Good fit).

\subsection{Structural model}

The measurement of this research uses Amos 22 software. Table 2 shows that CMIN/DF is 1.439 , signifying that it meets the requirements and can be categorized as a Good fit. RMSEA is 0.049, TLI is 0.812, and CFI is 0.899 , indicating good criteria. The goodness of fit value meets the stipulated requirements. In addition, a GFI value shows 0.899 (Marginal fit).

Table 2. Structural Model's Goodness of Fit.

\begin{tabular}{cccc}
\hline Goodness of fit & Criteria & $\begin{array}{c}\text { Model } \\
\text { Result }\end{array}$ & Description \\
\hline CMIN/DF & $\Omega 3.00$ & 1.439 & Good Fit \\
RMSEA & $\Omega 0.08$ & 0.049 & Good Fit \\
GFI & $m 0.90$ & 0.812 & Marginal Fit \\
TLI & $m 0.90$ & 0.907 & Good Fit \\
CFI & $m 0.90$ & 0.899 & Good Fit \\
\hline
\end{tabular}

\subsection{Hypothesis Testing}

The influence between variables can be said to be significant if the resulting significance value is $<0.05(\alpha=5 \%)$ or $\mathrm{CR}>1.96$. The results of the research hypothesis test show that there are 4 supported hypotheses and 11 unsupported hypotheses (Table 3).

Four hypotheses are supported, namely: online Customer Experience has a negative effect on Security Risk; Online Customer Experience has a negative effect on Time Risk; Privacy Risk has a negative effect on Online Purchase Intention; and Psychological Risk has a negative effect on Online Purchase Intention.

These results indicate that online service providers need to pay attention to consumers' safety, time, privacy, and psychological factors. When a customer experiences a disappointing online purchase, the customer will experience a negative perception of se- curity when making a transaction. In addition, when the purchase experience is disappointing, consumers also feel that they are wasting time as they spend time making a purchase.

Dome consumers also experience data theft when making online purchases. This makes consumers feel that shopping online is a risky thing from a security standpoint. As a result, customers are less likely to make repeat purchases.

When making purchases online, consumers will buy the items they need. When a disappointing experience occurs, consumers will be psychologically disturbed, for example: when making a complaint, making a return, or a conflict with the seller. Consumers' desire to make purchases decreases when they feel uncomfortable shopping online.

Table 3. Hypothesis Testing Results.

\begin{tabular}{|c|c|c|c|c|}
\hline & Est. & $\mathrm{CR}$ & $\mathrm{P}$ & Description \\
\hline $\mathrm{FR} \leftarrow \mathrm{OCE}$ & 0.155 & 1.682 & 0.092 & $\begin{array}{l}\text { Unsupport- } \\
\text { ed }\end{array}$ \\
\hline $\mathrm{PR} \leftarrow \mathrm{OCE}$ & -0.065 & -0.896 & 0.371 & $\begin{array}{l}\text { Unsupport- } \\
\text { ed }\end{array}$ \\
\hline $\mathrm{SR} \leftarrow \mathrm{OCE}$ & -0.211 & -1.872 & 0.061 & Supported \\
\hline $\mathrm{TR} \leftarrow \mathrm{OCE}$ & -0.486 & -3.654 & $* * *$ & Supported \\
\hline $\mathrm{SOR} \leftarrow \mathrm{OCE}$ & 0.076 & 0.728 & 0.467 & $\begin{array}{l}\text { Unsupport- } \\
\text { ed }\end{array}$ \\
\hline $\mathrm{PRR} \leftarrow \mathrm{OCE}$ & 0.093 & 1.171 & 0.241 & $\begin{array}{l}\text { Unsupport- } \\
\text { ed }\end{array}$ \\
\hline $\mathrm{PSR} \leftarrow \mathrm{OCE}$ & -0.043 & -0.467 & 0.641 & $\begin{array}{l}\text { Unsupport- } \\
\text { ed }\end{array}$ \\
\hline $\mathrm{OPI} \leftarrow \mathrm{FR}$ & -0.015 & -0.189 & 0.85 & $\begin{array}{l}\text { Unsupport- } \\
\text { ed }\end{array}$ \\
\hline $\mathrm{OPI} \leftarrow \mathrm{PR}$ & -0.06 & -0.598 & 0.55 & $\begin{array}{l}\text { Unsupport- } \\
\text { ed }\end{array}$ \\
\hline $\mathrm{OPI} \leftarrow \mathrm{SR}$ & 0.084 & 1.126 & 0.26 & $\begin{array}{l}\text { Unsupport- } \\
\text { ed }\end{array}$ \\
\hline $\mathrm{OPI} \leftarrow \mathrm{TR}$ & 0.058 & 0.914 & 0.361 & $\begin{array}{l}\text { Unsupport- } \\
\text { ed }\end{array}$ \\
\hline $\mathrm{OPI} \leftarrow \mathrm{SOR}$ & -0.047 & -0.75 & 0.453 & $\begin{array}{l}\text { Unsupport- } \\
\text { ed }\end{array}$ \\
\hline OPI $\leftarrow$ PRR & -0.202 & -2.06 & 0.039 & Supported \\
\hline $\mathrm{OPI} \leftarrow \mathrm{PSR}$ & -0.019 & -0.261 & 0.794 & $\begin{array}{l}\text { Unsupport- } \\
\text { ed }\end{array}$ \\
\hline $\mathrm{OPI} \leftarrow \mathrm{OCE}$ & 0.407 & 4.417 & $* * *$ & Supported \\
\hline
\end{tabular}

While the 11 unsupported hypotheses are: Online Customer Experience has no negative effect on Financial Risk; Online Customer Experience has no negative effect on Product Risk; Online Customer Experience has no negative effect on Social Risk; Online Customer Experience has no negative effect on Privacy Risk; Online Customer Experience has no negative effect on Psychological Risk; Financial Risk has no nega- 
tive effect on Online Purchase Intention; Product Risk has no negative effect on Online Purchase Intention; Security Risk has no negative effect on Online Purchase Intention; Security Risk has no negative effect on Online Purchase Intention; Social Risk has no negative effect on Online Purchase Intention; and Psychological Risk has no negative effect on Online Purchase Intention.

The results of this hypothesis test indicate that the customer experience in online shopping does not form a negative customer perception of financial, product, social, privacy, and psychological risks. The security, social, and psychological risks also do not make consumers have the desire not to make purchases online. Despite the security, social, and psychological risks, consumers are eager to make purchases online. This is because online shopping today eases consumers from various aspects, for example: saving time, do not have to leave the house, do not have to pay with cash, do not have to go from one store to another to compare items to be purchased, and an easy purchasing process.

\section{CONCLUSION}

The results show four hypotheses are supported and eleven hypotheses are not. This implies that consumers in Indonesia are generally used to shopping online. The increasing value of online shopping evidence this. Although online shopping has some risk elements, it is experienced by some customers, and many sellers are relatively cooperative when receiving complaints from customers. Transactions are also considered relatively safe because a marketplace chosen by the customers manages them. Transacted money will be paid out when the customer agrees to the payment, which attracts customers to make purchases online will continue to increase in the future.

\section{REFERENCES}

Ariffin, S.K., Mohan, T. \& Goh, Y.N. 2019. Influence of consumers 'perceived risk on consumers' online purchase intention. Journal of Research in Interactive Marketing 12(3): 309-327. DOI 10.1108 / JRIM-11-2017-0100.

Arshad, A., Zafar, M., Fatima, I. \& Khan, S.K. 2015. The Impact of Perceived Risk on Online Buying Behavior. International Journal of New Technology and Research 1(8): 13-18.

Bauer, R.A. \& Bauer, A.H. 1960. American mass society and mass media. Journal of Social Issues 10(3): 3-66. https://doi.org/10.1111/j.15404560.1960. tb00956.x

Bhatnagar, A., Misra, S., \& Rao, H. R. 2000. On risk, convenience, and internet shopping behavior. Communications of the ACM 43(11):98-114. https://doi.org/10.1145/353360. 353371

Bourlakis, M., Papagiannidis, S. \& Fox, H. 2008. Econsumer behavior: Past, present and future trajectories of an evolving retail revolution. International Journal of E-Business Research 4 (3): 6476. https://doi.org/10.4018/jebr. 2008070104

CNN Indonesia. 2020. Trends and Opportunities for the E-Commerce Industry in Indonesia. https://www.cnnindonesia.com/teknologi/2020020 5204206-206-472064/tren-dan-peluang-industrie-commerce-di-indonesia-2020. Downloaded on February 06, 2020.

Dabrynin, H. \& Zhang, J. 2019. The Investigation of the Online Customer Experience and Perceived Risk on Purchase Intention in China. Journal of Marketing Development and Competitiveness 13(2): 16-30.

Dowling, G.R. \& Staelin, R. 1994. A Model of Perceived Risk and Intended Risk-Handling Activity. Journal of Consumer Research 21: 119-134.

Forsythe, S.M. \& Shi, B. 2003. Consumer Patronage and Risk Perceptions in Internet Shopping. Journal of Business Research 56: 867-875.

Forsythe, S., Liu, C., Shannon, D., \& Gardner, L. C. 2006. Development of a scale to measure the perceived benefits and risks of online shopping. Journal of Interactive Marketing 20(2): 55-75. https://doi.org/10.1002/dir.20061

Garbarino, E. \& Strahilevitz, M. 2004. Gender differences in the perceived risks of buying online and the effects of receiving a site recommendation. Journal of Business Research 57(7): 768-775. https://doi.org/10.1016/s0148-2963 (02)00363-6

Grewal, D., Levy, M., \& Kumar, V. 2009. Customer experience management in retailing: An organizing framework. Journal of Retailing 85(1): 1-14. https://doi.org/10.1016/j.jretai.2009.01.001

Hsu, S.H. \& Bayarsaikhan, B.E. 2012. Factor Influencing on Online Shopping Attitude and Intention of Mongolian Consumer. The Journal of International Management Studies 7(4): 167-176.

iMarketology. 2020. What Does the Data Reveal About the Indonesian and Global Online Market? https://marketingcraft. getcraft.com/idarticles/apa-yang-didisclosed-data-tentang- 
pasar-online-indonesia-dan-global. Downloaded on May 19, 2020.

Johnston, R. \& Kong, X. 2011. The customer experience: A road-map for improvement. Managing Service Quality: An International Journal 21(1): 5-24. https://doi:10.1108/ 09604521111100225.

Kuhlmeier, D., \& Knight, G. 2005. Antecedents to internet-based purchasing: A multinational study. International Marketing Review 22(4): 460-473. https://10.1108/02651330510608460.

Masoud, E.Y. 2013. The Effect of Perceived Risk on Online Shopping in Jordan. European Journal of Business and Management 5(6): 76.

Pallab, P. 1996, Marketing on the Internet. Journal of Consumer Marketing 13: 27-39.

Paynter, J. \& Lim, J. 2001. Drivers and impediments to e-commerce in Malaysia. Malaysian Journal of Library and Information Science 6(2): 1-9.

Salisbury, W.D., Pearson, R.A., Pearson, A.W. \& Miller, D.W. 2001. Perceived security and worldwide web purchase intention. Industrial Management \& Data Systems 101(4): 165-177. https://doi.org /10.1108/02635570110390071

Sekaran, U. 2000. Research Methods for business: A Skill Building Approach. Singapore: John Wiley \& Sons, Inc.

Semeijn, J, Van-Riel, A.C.R \& Ambrosini, A.B. 2004. Consumer evaluations of store brands: effects of store image and product attributes, Journal of Retailing and Consumer Services 11: 247258. DOI: $10.1016 / \mathrm{S} 0969-6989$

Soltanpanah, H., Shafe'ei, R., \& Mirani, V. 2012. A Review of the Literature of Perceived Risk and Identifying its Various Facets in e-Commerce by Customers: Focusing on Developing Countries. African Journal of Business Management 6(8): 2888-2896.

Ueltschy, L.C., Krampf, R.F. \& Yannopoulos, P. 2004. A Cross-National Study of Perceived Consumer Risk Towards Online (Internet) Purchasing. Multinational Business Review 12(2): 59-82. DOI: 10.1108/1525383X 200400010.

Verhoef, P.C., Lemon, K.N., Parasuraman, A., Roggeveen, A., Tsiros, M. \& Schlesinger, L.A. 2009. Customer experience creation: Determinants, dynamics and management strategies. Journal of Retailing 85(1): 31-41. DOI: https://10. 1016-j.jretai. 2008.11.001.

Wijayanto, S.H. 2008. Structural Equation Modeling with LISREL 8.8. Yogyakarta: Graha Ilmu.

Zikmund, W.G., Carr, B.J., Griffin, M. \& Babin, B.J. 2013. Business Research Method. Fort Worth: Dryden Press.

Zhou, L., Dai, L., \& Zhang, D. 2007. Online shopping acceptance model - a critical survey of consumer factors in online shopping. Journal of Electronic Commerce Research 8(1): 41-62. 